\title{
Germination and seedling growth of rice (Oryza sativa L.) as affected by varying concentrations of loom-dye effluent
}

\author{
${ }^{凶}$ Md. Arifur Rahman ${ }^{1}$, Md. Sohanur Rahman ${ }^{2}$, K.M. Mohiuddin ${ }^{1}$, Md. Akhter Hossain Chowdhury ${ }^{1}$, \\ and Md. Abul Khair Chowdhury ${ }^{1}$
}

${ }^{1}$ Department of Agricultural Chemistry, Bangladesh Agricultural University, Mymensingh-2202, Bangladesh

${ }^{2}$ Entomology Department, Pest Management Division, Bangladesh Jute Research Institute, Dhaka-1207, Bangladesh

\begin{tabular}{l} 
ARTICLE INFO OPENOACcess \\
\hline Article history: \\
Received : 16 February 2019 \\
Accepted : 14 May 2019 \\
Published: 30 June 2019 \\
\hline
\end{tabular}

Keywords:

Rice, Germination, Dye effluent,

Heavy metal and Toxicity

Correspondence:

Md. Arifur Rahman

凶: arif.bau11@gmail.com

\begin{abstract}
Indiscriminate discharge of industrial effluent has become a serious problem for the agro-ecological environment in most of the areas of Bangladesh. The effects of loom-dye effluents on seed germination and early seedling growth of rice (Oryza sativa L.) were investigated by conducting an experiment in the laboratory of the Department of Agricultural Chemistry of Bangladesh Agricultural University, Mymensingh. Three types of loom-dye effluents were applied in sterilized petridishes at different loading ratios. Seven treatments (i.e., $\mathrm{T}_{0}, \mathrm{~T}_{1}, \mathrm{~T}_{2}, \mathrm{~T}_{3}, \mathrm{~T}_{4}, \mathrm{~T}_{5}$ and $\mathrm{T}_{6}$ with $0,5,10,25,50,75$ and $100 \%$ effluent, respectively) of each effluent were used following completely randomized design (CRD) and replicated three times. Subsequently, $\mathrm{Pb}, \mathrm{Fe}, \mathrm{Zn}, \mathrm{Mn}$ and $\mathrm{Cr}$ accumulation were also investigated in the harvested rice seedlings. Rice seed showed a significant difference in germination percentage with varying levels of effluent application at different days after setting of germination. The decreased seed germination rate and seedling growth of rice were observed with increased concentration of loom-dye effluents. The highest germination speed $(97.8 \%)$ was obtained from control whereas the lowest germination speeds were obtained from $\mathrm{T}_{5}$ of black, and $\mathrm{T}_{6}$ of both black and violet effluents. Phytotoxic effects of loom-dye effluents on germination and radical length were extreme at $100 \%$ effluent concentration having the order of black > violet > pink. The maximum radical length $(6.4 \mathrm{~cm})$ and plumule length $(7.5 \mathrm{~cm})$ were observed with $\mathrm{T}_{1}$ of pink dye effluent whereas the minimum length of radical and plumule were obtained from $\mathrm{T}_{6}$ treatment of the effluents. The highest fresh weight $\left(39.8 \mathrm{mg}\right.$ petridish $\left.{ }^{-1}\right)$, dry weight $(5.7 \mathrm{mg}$ petridish $^{-1}$ ) and seedling vigor index $(746.7 \%)$ were also observed from $\mathrm{T}_{1}$ of pink dye effluent. The maximum uptake of $\mathrm{Pb}, \mathrm{Fe}, \mathrm{Mn}$ and $\mathrm{Zn}$ was $0.48,3.81,0.79$ and $0.13 \mu \mathrm{g} \mathrm{g}^{-1}$, respectively. The uptake of $\mathrm{Cr}$ was below the detectable limit. Total heavy metal accumulation in rice was in the following order: $\mathrm{Fe}>\mathrm{Mn}>\mathrm{Pb}>\mathrm{Zn}>\mathrm{Cr}$. Results showed that the higher concentration of loom-dye effluent showed the higher toxic effects on different parameters of germination and early seedling growth compared with the lower effluent concentrations.
\end{abstract}

\section{Introduction}

Pollution of the natural environment by industrial effluent has become a matter of major concern because of containing a variety of metallic pollutants with harmful chemical constituents of undesirable concentration. Being an agricultural country, industrialization in Bangladesh is occurring in an expanding stage. Recently, the deterioration of water resources with the rapid growth of industries (sugar, paper, tannery, textile and dyeing industries) in the country has come into the discussion. It generally disrupts the habitats of the living organisms when discharged into the environment without proper treatment (David and Rajan, 2015). Due to poor enforcement of existing laws, the discharge of industrial effluent into water bodies consequently entering into agro-environment is going to become a major threat for agricultural crop cultivation. Industrial effluents are considered as one of the most important factors responsible for the low productivity of crops causing serious pollution to water and soil systems (Otokunefor and Obiukwu, 2005; Konwar and Jha, 2010). The effluents may affect photosynthetic organisms (Coulibaly et al., 2003; Stolt et al., 2006; Jamali et al., 2007) because of its composition of complex mixture of waste substances namely, organochlorine-based pesticides, heavy metals, pigments and dyes, harmful gases, and several organic and inorganic compounds (Balaji et al., 2012; Rohit and Ponmurugan, 2013).

A dyeing industry having 10 tons of production capacity generates nearly 100 to $150 \mathrm{~m}^{3}$ of wastewater per hour (Haque, 2008). Effluent from loom-dye industries is considered as an important pollutant mixing with organic and inorganic compounds, acids, alkalis, suspended solids, heavy metals like lead, cadmium, chromium, iron, manganese, zinc and other materials. The heavy metal contamination by the effluents ends up 
infiltrating ecological compartments contaminating agriculture fields and rivers. The continuous irrigation of agricultural land with the effluent wastewater causes heavy metal accumulation in the grown crops (Sharma et al., 2007; Marshall et al., 2007). When this effluent discharged into the watercourses, they restrict the light penetration and inhibit the activities of aquatic lives (Parameswari and Udayasooriyan, 2013). On the other hand, effluent produced from the loom-dyeing industries is also a source of irrigation water since it contains nutrients having the potential use in agricultural crop cultivation, especially in the area of water scarcity. But, this practice of using the effluents for irrigation purpose has been unexpected because of the adverse effects of them on plants depending on the crop varieties, types and concentrations of toxic materials present (Hassan et al., 2013). Rice (Oryza sativa L.) is one of the most important cereal crops providing food for nearly a half of the world population (Panich-pat and Srinives, 2009) and contributing with one-fifth of the calories consumed by human's worldwide (Welch and Graham, 2005). About 90 percent of the total rice is cultivated in Asia (Salim et al., 2003). Recently, some studies on the effects of different industrial effluents on germination and seedling growth of rice had been reported in different parts of the world (Pandey et al., 2008; Medhi et al., 2008; Samuel and Muthukkaruppan, 2011; Mahesh et al., 2013; Raju et al., 2015). To the best of our knowledge, in Bangladesh, no published report is found on the effects of loom-dye effluent on germination and early growth of rice. Therefore, this research work was designed to study the effects of loom-dye effluent collected from various loom-dyeing industries of Sirajganj on germination and early seedling growth of rice as a preliminary step before the field trials.

\section{Materials and Methods}

Loom-dye effluents were collected from different dyeing industries of Bhangabari, Dhukuriabera and Rajapur of Belkuchi under Sirajganj district in $2 \mathrm{~L}$ plastic containers. The collected dye effluent samples were analyzed for their physico-chemical properties (Table 1) in the laboratory of Department of Agricultural Chemistry, Bangladesh Agricultural University, Mymensingh as per the standard methods (APHA, 2012). The detailed procedure was followed as described by Rahman et al. (2018). Germination experiment was performed in Postgraduate Research Laboratory of the Department of Agricultural Chemistry, Bangladesh Agricultural University, Mymensingh during the period of August to October 2017 and total sixty-three petridishes were lined with double layer of filter paper. Prior to the experimental setup, the petridishes were sterilized properly and incubated at $28 \pm 2^{\circ} \mathrm{C}$ for germination in dark (ISTA, 1985). Rice var. BRRI dhan28 collected from Bangladesh Agricultural Development Corporation (BADC), Mymensingh, was chosen as a test crop for this study. Fifteen healthy and uniform rice seeds were selected and thoroughly washed with distilled water to remove dust and fungal traces followed by sterilization with $0.1 \% \mathrm{HgCl}_{2}$.

Table 1. Physico-chemical properties of used loom-dye effluent

\begin{tabular}{lccc}
\hline Parameters & Effluent-1 from Bhangabari & Effluent-2 from Dhukuriabera & Effluent-3 from Rajapur \\
\hline Colour & Pink & Violet & Black \\
Odour & Slightly pungent & Pungent & Very pungent \\
Temperature $\left({ }^{\circ} \mathrm{C}\right)$ & 36.5 & 37.0 & 37.0 \\
pH & 12.86 & 12.74 & 12.89 \\
Electrical conductivity $(\mathrm{EC})\left(\mu \mathrm{S} \mathrm{cm}^{-1}\right)$ & 782 & 2947 & 4380 \\
Total dissolved solids (TDS) $\left(\mathrm{mg} \mathrm{L}^{-1}\right)$ & 1320 & 3584 & 5382 \\
Calcium $\left(\mathrm{mg} \mathrm{L}^{-1}\right)$ & 28.06 & 46.10 & 30.06 \\
Magnesium $\left(\mathrm{mg} \mathrm{L}^{-1}\right)$ & 6.42 & 5.50 & 2.48 \\
Potassium $\left(\mathrm{mg} \mathrm{L}^{-1}\right)$ & 9.52 & 9.58 & 19.39 \\
Sodium $\left(\mathrm{me} \mathrm{L}^{-1}\right)$ & 70.95 & 88.06 & 109.22 \\
Sulphate $\left(\mathrm{m} \mathrm{L}^{-1}\right)$ & 69.67 & 69.16 & 68.25 \\
Phosphate $\left(\mathrm{mg} \mathrm{L}^{-1}\right)$ & 17.85 & 21.45 & 38.28 \\
Iron $\left(\mathrm{mg} \mathrm{L}^{-1}\right)$ & 3.78 & 13.37 & 8.18 \\
Zinc $\left(\mathrm{mg} \mathrm{L}^{-1}\right)$ & 0.15 & 0.41 & 0.38 \\
Manganese $\left(\mathrm{mg} \mathrm{L}^{-1}\right)$ & 0.43 & 1.72 & 0.18 \\
Copper $\left(\mathrm{mg} \mathrm{L}^{-1}\right)$ & 0.07 & 0.49 & 0.17 \\
Lead $\left(\mathrm{mg} \mathrm{L}^{-1}\right)$ & 0.63 & 1.14 & 1.12 \\
Cadmium $\left(\mathrm{mg} \mathrm{L}^{-1}\right)$ & 0.013 & 0.009 & 0.007 \\
\hline
\end{tabular}

Seven treatment levels viz., $\mathrm{T}_{0}, \mathrm{~T}_{1}, \mathrm{~T}_{2}, \mathrm{~T}_{3}, \mathrm{~T}_{4}, \mathrm{~T}_{5}$ and $\mathrm{T}_{6}$ with $0,5,10,25,50,75$ and $100 \%$ loom-dye effluent were used following completely randomized design (CRD) with three replications. Seedlings were harvested at 7 days after sowing (DAS) of seed. The germination percentage was measured using the following formula (Raun et al., 2002).
Germination $(\%)=\frac{\text { Number of seeds germinated }}{\text { Total number of seeds set for test }} \times 100$

Germination energy and germination capacity were calculated in percentage of germinated seed at 3 and 7 DAS, respectively (Bam et al., 2006). Germination speed was measured by using the following formula (Krishnaswamy and Seshu, 1990). 
Speed of germination (\%)

$$
=\frac{\text { Number of seed germinated at } 72 \mathrm{~h}}{\text { Number of seed germinated at } 168 \mathrm{~h}} \times 100
$$

Relative toxicity of dye effluent on the germination over control was calculated by using the following formula (Chapagain, 1991).

Relative Toxicity $(\%)=\frac{x-y}{x} \times 100$

Where, $\mathrm{x}=$ Germination percentage in control at a particular hour of incubation; $y=$ Germination percentage in the presence of effluent at the same hour of incubation.

Phytotoxicity of the dye effluent on seedling growth was calculated by using the following formula (Chou and Lin, 1976).

Phytotoxicity (\%)

$$
=\frac{\text { Radical lengthof control }- \text { Radical length of test }}{\text { Radical lengthof control }} \times 100
$$

Seedling vigor index was calculated using the formula proposed by Abdul-Baki and Anderson (1973).

Vigor index $=$ Germination percentage $\times$ Length of seedling

The seedlings were collected from each treatment and their fresh weights were measured. Then seedlings were dried in an oven at $60{ }^{\circ} \mathrm{C}$ for 24 hours to measure dry weights. The results were presented as means $\pm \mathrm{SE}$ (standard error of means) and these were analyzed using SPSS (20.0) and Microsoft Excel program.

\section{Results and Discussion}

\section{Effects of loom-dye effluent on seed germination}

Rice seed showed the significant difference of germination energy and capacity with varying level of effluent application at 3 and 7 DAS, respectively (Table 2). The maximum germination rate $(100 \%)$ at 3 DAS was recorded from control treatment $\left(\mathrm{T}_{0}\right)$ followed by $\mathrm{T}_{1}$ of pink and black dye effluent. The highest effluent concentration $\left(T_{6}\right)$ resulted in the minimum germination percentage at 3 DAS. The increasing rate of effluent application significantly affected germination capacity of rice. The highest seed germination capacity $(100 \%)$ was recorded at control and $T_{1}$ of the effluents whereas the lowest germination at 7 DAS was found from $\mathrm{T}_{6}$ treatment of black dye effluent. Black dye effluent inhibited the germination capacity more than other effluents with the increased level of effluent application. The germination percentage of this study was supported by the findings of Mahesh et al. (2013) who found a decreasing rate of rice seed germination ranging between $100.00-41.50 \%$ among five cultivars. Previous researchers also found the same trend of germination percentage with the increasing levels of effluent (Singh et al., 2007; Pandey et al., 2008; Samuel and Muthukkaruppan, 2011; Rahman et al., 2018).

\begin{tabular}{|c|c|c|c|c|c|c|c|c|c|}
\hline \multirow{2}{*}{$\begin{array}{c}\text { Effluent } \\
\text { Conc. }(\%)\end{array}$} & \multicolumn{3}{|c|}{ Germination energy (3 DAS) } & \multicolumn{3}{|c|}{ Germination capacity (7 DAS) } & \multicolumn{3}{|c|}{ Germination Speed } \\
\hline & Pink & Violet & Black & Pink & Violet & Black & Pink & Violet & Black \\
\hline $\mathrm{T}_{0}$ & $97.8 \pm 2.7$ & $97.8 \pm 2.7$ & $97.8 \pm 2.7$ & $100 \pm 0.0$ & $100 \pm 0.0$ & $100 \pm 0.0$ & $97.8 \pm 2.2$ & $97.8 \pm 2.2$ & $97.8 \pm 2.2$ \\
\hline $\mathrm{T}_{1}$ & $95.6 \pm 7.2$ & $91.1 \pm 3.3$ & $95.6 \pm 6.0$ & $100 \pm 0.0$ & $100 \pm 0.0$ & $100 \pm 0.0$ & $95.6 \pm 2.2$ & $93.2 \pm 0.2$ & $95.6 \pm 2.2$ \\
\hline $\mathrm{T}_{2}$ & $91.1 \pm 4.4$ & $88.9 \pm 4.4$ & $91.1 \pm 2.9$ & $97.8 \pm 5.0$ & $97.8 \pm 4.4$ & $97.8 \pm 6.7$ & $93.2 \pm 0.2$ & $88.9 \pm 4.4$ & $93.3 \pm 3.8$ \\
\hline $\mathrm{T}_{3}$ & $88.9 \pm 5.1$ & $84.4 \pm 3.3$ & $4.4 \pm 2.2$ & $95.6 \pm 2.9$ & $93.3 \pm 4.4$ & $8.9 \pm 2.2$ & $93.2 \pm 3.9$ & $97.8 \pm 5.3$ & $50.0 \pm 2.8$ \\
\hline $\mathrm{T}_{4}$ & $84.4 \pm 1.7$ & $82.2 \pm 2.9$ & $2.2 \pm 1.6$ & $95.6 \pm 2.9$ & $86.7 \pm 3.8$ & $6.7 \pm 1.7$ & $88.4 \pm 2.2$ & $88.2 \pm 2.1$ & $33.3 \pm 3.3$ \\
\hline $\mathrm{T}_{5}$ & $31.1 \pm 2.2$ & $26.7 \pm 2.2$ & $0 \pm 0.0$ & $44.4 \pm 2.2$ & $37.8 \pm 2.9$ & $4.4 \pm 1.7$ & $70.6 \pm 7.6$ & $71.1 \pm 10.6$ & $0.0 \pm 0.0$ \\
\hline $\mathrm{T}_{6}$ & $8.9 \pm 1.7$ & $0 \pm 0.0$ & $0 \pm 0.0$ & $13.3 \pm 1.7$ & $8.9 \pm 2.2$ & $0 \pm 0.0$ & $66.7 \pm 16.7$ & $0.0 \pm 0.0$ & $0.0 \pm 0.0$ \\
\hline
\end{tabular}

Table 2. Effects of loom-dye effluent on seed germination parameters of rice (mean $\pm \mathrm{SE})$

Legend: $\mathrm{T}_{0}=0, \mathrm{~T}_{1}=5, \mathrm{~T}_{2}=10, \mathrm{~T}_{3}=25, \mathrm{~T}_{4}=50, \mathrm{~T}_{5}=75$ and $\mathrm{T}_{6}=100 \%$ loom-dye effluent

Suppression of germination might be caused due to the reduction of water absorption by seeds with high concentrations of effluent which ultimately affect the energy forming compounds (Kannan and Upreti, 2008) and the presence of a higher amount of total solids and heavy metals (Palanivel et al., 2004; Malla and Mohanty, 2005).

\section{Effects of loom-dye effluent on germination speed}

Types of effluents and their concentrations affected the germination speed of rice seed significantly (Table 2). Seed germination speed was inhibited by the increasing concentration of loom-dye effluent in comparison with control. The highest germination speed (97.8\%) was obtained from control whereas the lowest germination speeds were found from $\mathrm{T}_{5}$ and $\mathrm{T}_{6}$ of black and $\mathrm{T}_{6}$ of violet effluent. The speed of germination increased up to $\mathrm{T}_{3}$ of pink dye effluent and was decreased with the increasing level of concentration of other effluents. A similar result was found by Rahman et al. (2018) in case of seed germination speed of red amaranth.

\section{Relative toxicity of loom-dye effluent on seed germination}

Relative toxicity of loom-dye effluents on seed germination of rice at 3 and 7 DAS have been presented in Fig. 1. Control treatment showed no toxicity. Among the treatment, the minimum relative toxicity was found with $\mathrm{T}_{1}$ and the maximum was from $100 \%$ concentration $\left(\mathrm{T}_{6}\right)$ of the effluent. Above $\mathrm{T}_{2}$, the relative toxicity was significantly increased and maximum relative toxicity was obtained from black dye effluent. Similar results of toxicity of different effluents were also found previously (Rani and Alikhan, 2007; David and Rajan, 2015; Rahman et al., 2018). 


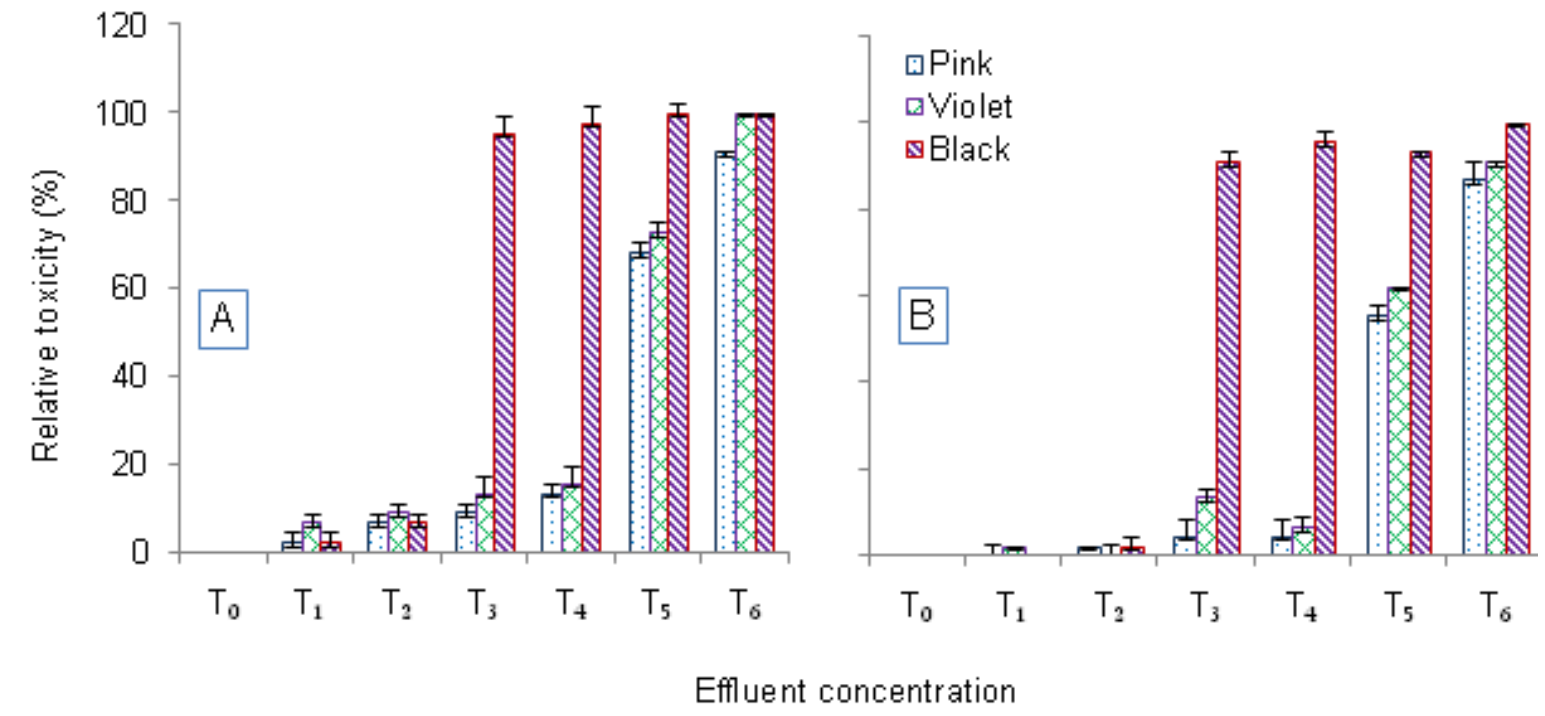

Fig. 1. Relative toxicity of loom-dye effluent on rice seed germination at 3 DAS (A) and 7 DAS (B). The error bars indicate the standard error of means

Effects of loom-dye effluent on radical and plumule lengths

The lengths of radical and plumule of rice varied with effluent types and their different concentrations (Fig. 2). The lengths of radical and plumule showed a significant reduction at 7 DAS with the increasing levels of the effluent. The maximum radical length $(6.4 \mathrm{~cm})$ and plumule length $(7.5 \mathrm{~cm})$ were observed with $T_{1}$ of pink dye effluent and the minimum lengths of radical and plumule were obtained from $\mathrm{T}_{6}$ of the effluents and no radical was produced from $T_{6}$ of black dye effluent. The study showed clear inhibition of plumule and radical lengths, however, the radical length was more affected than the plumule by the application of comparatively higher concentrations of effluents (Oncel et al., 2000). The germinated seeds did not get enough oxygen for the toxicity of effluent solution and the radical continuously remained in direct contact with the effluent might be responsible for affecting cell multiplication or the growth (Kannan and Upreti, 2008). The lower effluent concentration might promote the growth because of containing plant nutrients (Augusthy and Annsherin, 2001). This result was in line with the findings of Mahesh et al. (2013) who obtained a decreasing length of radical $(23.43-0.90 \mathrm{~cm})$ and plumule $(16.40-2.20 \mathrm{~cm})$ of five paddy cultivars. Pandey et al. (2008) studied the toxicity level of distillery effluent on the early growth of rice and maize, and found a decreasing rate of root and shoot lengths with increasing effluent concentration. Many researchers observed inhibitory effects of various effluents on radical and plumule length of different plant species (Singh et al., 2006; Nawaz et al., 2006; Vijayaragavan et al., 2006; Yousaf et al., 2010; Vaithiyanathan and Sundaramoorthy, 2017; Rahman et al., 2018).
Effects of loom-dye effluent on seedling fresh and dry weights

The fresh and dry weights of rice seedling increased with lowering of the effluent concentration up to $T_{1}$ and decreased with higher concentration (Table 3). The highest fresh weight $\left(39.8 \mathrm{mg}\right.$ petridish $\left.^{-1}\right)$ and dry weight $\left(5.7 \mathrm{mg}\right.$ petridish $\left.{ }^{-1}\right)$ were observed from $\mathrm{T}_{1}$ of pink dye effluent. Black dye effluents lowered the fresh and dry weight of the seedlings significantly than others. The minimum fresh weight and dry weights were recorded from $T_{6}$ of the effluent. This result was in conformity with previous reports (Sarathchandra et al., 2006; Rani and Alikhan, 2007; Vaithiyanathan and Sundaramoorthy, 2017; Rahman et al., 2018). The promotion of seedling growth by lower concentration of effluents might be due to creating a favorable environmental condition for the germination utilizing the nutrients present in the effluent (Augusthy and Annsherin, 2001; Suresh et al., 2014; Vinod, 2014).

Phytotoxicity of loom-dye effluent on seedling growth The increased levels of effluent concentrations inhibited the seedling growth of rice significantly (Table 3 ). The effluent application at the concentrations of $\geq T_{2}$ inhibited the total dry matter production, plumule and radical lengths of rice seedlings. The maximum phytotoxicity was observed with the treatment $T_{6}$ of black and the minimum was recorded from control. Except control, minimum phytotoxicity was obtained from $T_{1}$ followed by $T_{2}$ irrespective of the effluents. The highest phytotoxicity was observed from black dye effluent whereas, pink dye effluent showed less phytotoxicity. Due to the high $\mathrm{pH}, \mathrm{EC}$, TDS and metallic contents of loom-dye effluent, high level of phytotoxicity might be occurred. Similar toxic effects of industrial effluent were observed by David and Rajan (2015) and Rahman et al. (2018). 

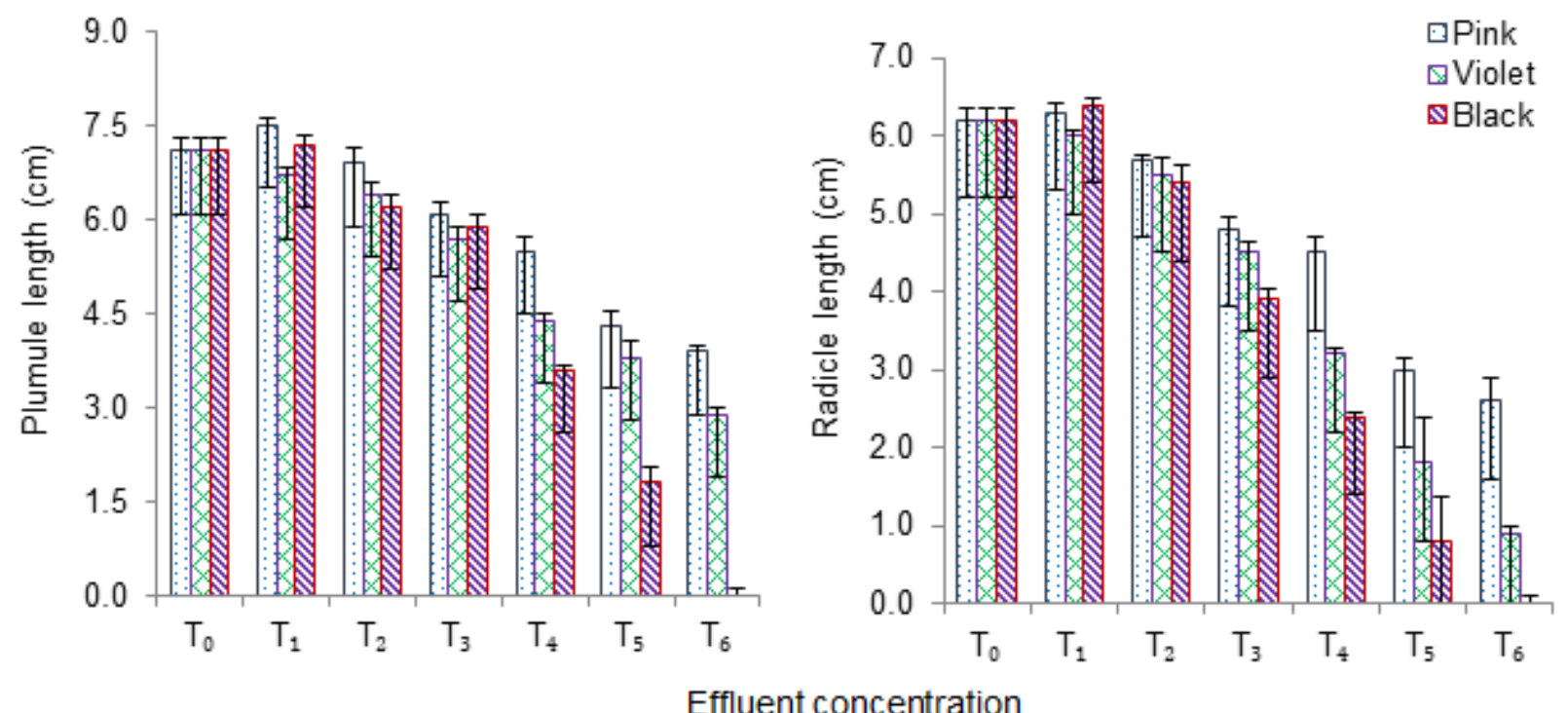

Fig. 2. Effects of loom-dye effluent on plumule and radical lengths of rice. The error bars indicate the standard error of means

Table 3. Effects of loom-dye effluent on seedling growth parameters of rice and phytotoxicity of the effluents $(\mathrm{mean} \pm \mathrm{SE})$

\begin{tabular}{|c|c|c|c|c|c|c|c|c|c|}
\hline \multirow{2}{*}{$\begin{array}{c}\text { Effluent } \\
\text { Conc. (\%) }\end{array}$} & \multicolumn{3}{|c|}{ Fresh weight (mg petridish $\left.{ }^{-1}\right)$} & \multicolumn{3}{|c|}{ Dry weight $\left(\mathrm{mg} \mathrm{petridish}^{-1}\right)$} & \multicolumn{3}{|c|}{ Phytotoxicity (\%) } \\
\hline & Pink & Violet & Black & Pink & Violet & Black & Pink & Violet & Black \\
\hline$\overline{\mathrm{T}_{0}}$ & $39.3 \pm 1.13$ & $39.3 \pm 1.13$ & $39.3 \pm 1.13$ & $.5 \pm 0.31$ & $5.5 \pm 0.31$ & $5.5 \pm 0.31$ & $0.0 \pm 0.00$ & $0.0 \pm 0.00$ & $0.0 \pm 0.00$ \\
\hline $\mathrm{T}_{1}$ & $39.8 \pm 0.94$ & $35.5 \pm 1.34$ & $34.6 \pm 1$ & $5.7 \pm 0.29$ & $5.1 \pm 0$ & $5.2 \pm 0$ & $3.8 \pm 1.97$ & 2.2 & 13 \\
\hline $\mathrm{T}_{2}$ & $37.9 \pm 0.88$ & $32.8 \pm 1.75$ & $33.2 \pm 1.99$ & $3 \pm 0.47$ & $4.7 \pm 0.52$ & $4.8 \pm 0$ & $7.1 \pm 1.09$ & 9.8 & $11.5 \pm 0.95$ \\
\hline $\mathrm{T}_{3}$ & $32.4 \pm 2.44$ & $28.7 \pm$ & $28.5 \pm$ & $4.7 \pm 0.59$ & 4.1 & $4.1 \pm$ & 38 & 2.38 & 2.50 \\
\hline $\mathrm{T}_{4}$ & $28.4 \pm 2.38$ & $25.1 \pm 0.72$ & $25.7 \pm 2.26$ & $4.1 \pm 0.54$ & $3.6 \pm 0.32$ & $3.8 \pm 0.55$ & $26.2 \pm 3.41$ & $47.5 \pm 0.95$ & $60.1 \pm 2.38$ \\
\hline $\mathrm{T}_{5}$ & $22.2 \pm 1.44$ & $17.6 \pm 1.12$ & $14.3 \pm 0.67$ & $3.2 \pm 0.34$ & $2.5 \pm 0.24$ & $2.06 \pm 0.21$ & $50.3 \pm 2.38$ & $71.0 \pm 9.29$ & $86.9 \pm 3.28$ \\
\hline $\mathrm{T}_{6}$ & $17.1 \pm 0.82$ & $9.2 \pm 1.97$ & $0.0 \pm 0.00$ & $2.5 \pm 0.19$ & $1.35 \pm 0.21$ & $0.0 \pm 0.00$ & $57.9 \pm 4.76$ & $84.2 \pm 5.21$ & $100.0 \pm 0.00$ \\
\hline
\end{tabular}

Legend: $\mathrm{T}_{0}=0, \mathrm{~T}_{1}=5, \mathrm{~T}_{2}=10, \mathrm{~T}_{3}=25, \mathrm{~T}_{4}=50, \mathrm{~T}_{5}=75$, and $\mathrm{T}_{6}=100 \%$ loom-dye effluent

Effects of loom-dye effluent on seedling vigor index

The decreased vigor index (SVI) of rice seedling observed with the increasing level of effluent concentrations has been presented in Fig. 3. The highest seedling vigor index $(746.7 \%)$ was observed with $\mathrm{T}_{1}$ of pink dye effluent whereas, the lowest was recorded from $\mathrm{T}_{6}$ of the effluents at 7 DAS. The variation of SVI might be due to the stress levels of different effluent concentrations. Black and violet effluents imposed more inhibition on SVI than the pink dye effluent. Previous reports also showed higher SVI with a lower effluent concentration (Rani and Alikhan, 2007; Singh et al., 2007; Rahman et al., 2018).

Effects of loom-dye effluent on heavy metal uptake by seedlings

Heavy metal uptake by rice seedlings has been presented in Fig. 4. The loom-dye effluent collected from different industries showed increased heavy metal accumulation in seedlings compared with fresh water treatment. Increased uptake of heavy metals was found with increasing effluent concentrations up to $\leq T_{5}$ of dye effluents. It could be due to the adverse effect of the higher concentration of effluents on plant cells which impaired the tissues leading to lower uptake of metals
(Balakrishnan et al., 2008; Farook et al. 2008; Yousuf et al. 2010; Oguntade et al., 2014).

Lead $(\mathrm{Pb})$ contents in rice seedlings varied significantly with different doses of effluent application. The highest $\mathrm{Pb}$ content $\left(0.48 \mu \mathrm{g} \mathrm{g}^{-1}\right)$ in rice seedling was obtained from $T_{5}$ of the black dye effluent and the lowest from the control. This was comparable to average $\mathrm{Pb}$ concentrations of $0.25 \mu \mathrm{g} \mathrm{g}^{-1}$ in field rice sites in China (Williams et al. 2012). The highest Fe uptake was 3.81 $\mu \mathrm{g} \mathrm{g}^{-1}$, which was obtained from seedlings grown with $\mathrm{T}_{4}$ of violet dye effluent. The maximum $\mathrm{Mn}$ and $\mathrm{Zn}$ uptakes were 0.79 and $0.13 \mu \mathrm{g} \mathrm{g}^{-1}$, respectively obtained from $\mathrm{T}_{3}$ of violet dye effluent. The uptake of $\mathrm{Cr}$ was completely absent in all the treatments. The order of total heavy metal accumulation in the crop was in the following order: $\mathrm{Fe}>\mathrm{Mn}>\mathrm{Pb}>\mathrm{Zn}>\mathrm{Cr}$.

This finding was in line with the previous reports (Kisku et al., 2000; Echem, 2014; Farooq et al., 2008; Singh et al., 2010; Oguntade et al., 2014). The concentrations Cr, $\mathrm{Mn}, \mathrm{Pb}$ and $\mathrm{Zn}$ in typical agricultural crops were from $0.2-1.0,15.0-100.0,0.10-10.0,15.0-200.0 \mathrm{mg} \mathrm{kg}^{-1}$ dry weight, respectively proposed by Allaway (1968). 


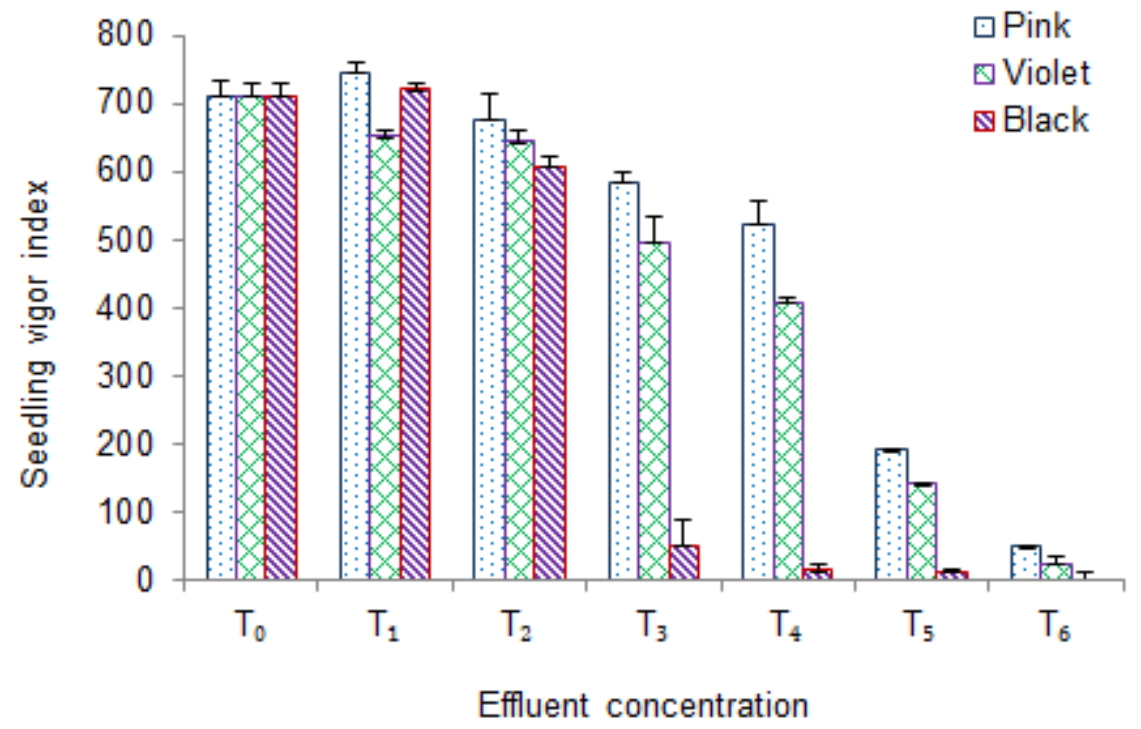

Fig. 3. Effects of loom-dye effluent on vigor index of rice seedling. The error bars indicate the standard error of means
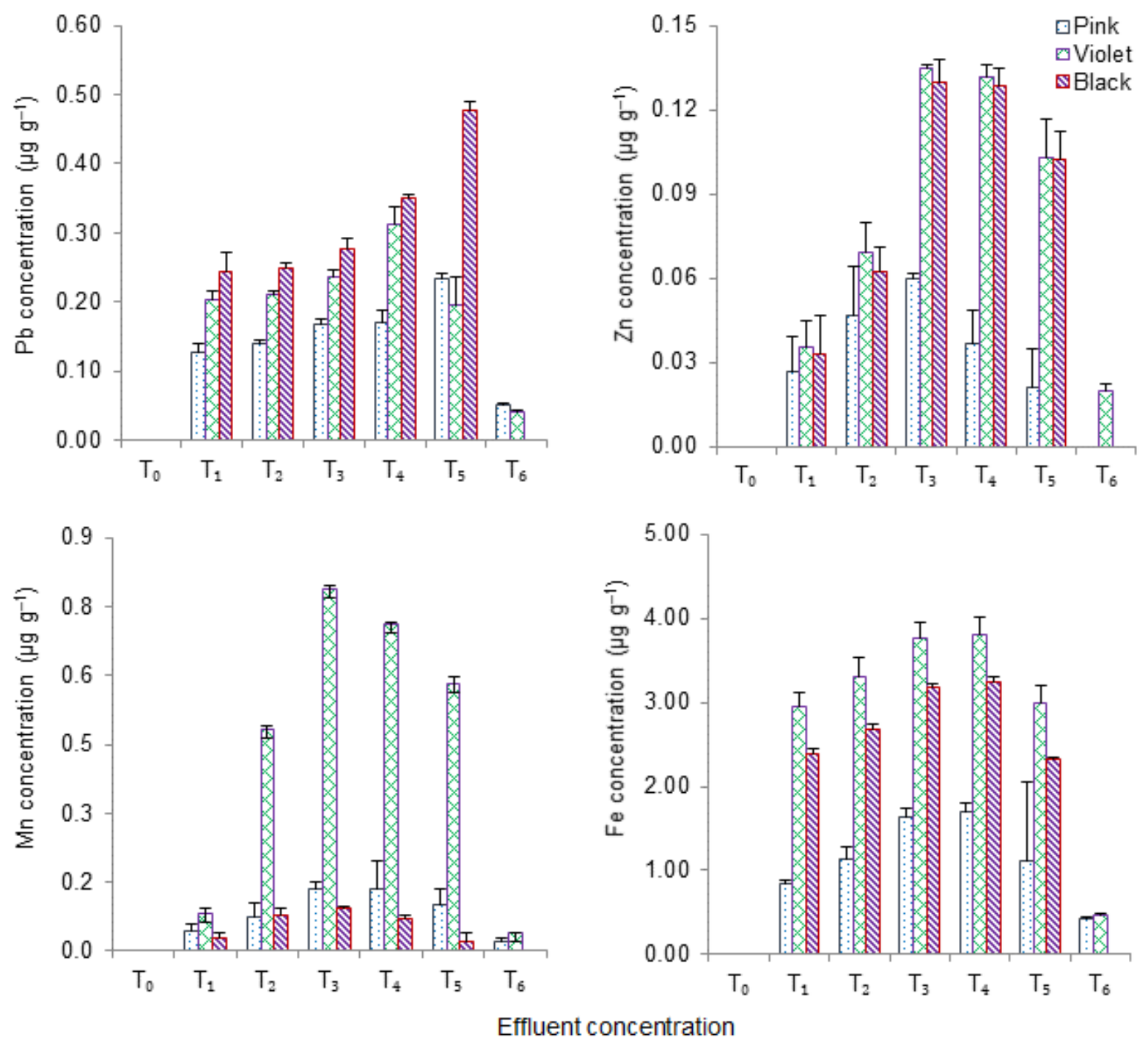

Fig. 4. Heavy metal accumulations of rice seedlings harvested at 7 DAS. The error bars indicate the standard error of means 


\section{Conclusion}

Based on the experimental observations, it was found that the declined rate of germination percentage, germination speed, radical length, plumule length and seedling vigor index were found with increasing effluent concentrations. The pink dye effluent having lower EC and TDS comparatively imposed a less adverse effect on different parameters. The overall results suggested that the loom-dye effluent should not be used for seed germination and early seedling growth of rice without proper treatment.

\section{References}

Abdul-baki, A.A. and Anderson, J.O., 1973. Vigor determination in soybean application of dairy manure on germination and emergence of some selected crops. Journal of Environmental Quality, 3: 396-399. https://doi.org/10.2134/jeq1973.00472425000200030022x

Allaway, W.H., 1968. Agronomic control over the environmental cycling of trace elements. Advances in Agronomy, 20: 235 274. https://doi.org/10.1016/S0065-2113(08)60858-5

APHA. 2012. Standard Methods for the Examination of Water and Wastewater, 22nd edition. American Public Health Association, Washington, DC, USA.

Augusthy, P.O. and Annsherin, M., 2001. Effect of factory effluent on seed germination and seedling growth of Vigna radiatus (L.). Journal of Environmental Research, 22(2): 137-139.

Balaji, V., Vinayagamoorthi, D., Palanisamy, A., and Anbalagan, S., 2012. Degradation of Reactive Red HE7B and Yellow FN2R dyes by fungal isolates. Journal of Academia and Industrial Research, 1(3): 132-136.

Balakrishnan, M., Antony, S.A., Gunasekaran, S. and Natarajan, R.K. 2008. Impact of dyeing industrial effluents on the groundwater quality in Kancheepuram, India. Indian Journal of Science and Technology, 1: 1-8.

Bam, R.K., Kumaga, F.K., Ofori, K. and Asieudu, E.A., 2006. Germination, vigor and dehydrogenase activity of naturally aged rice (Oryza sativa L.) seeds soaked in potassium and phosphorous salts. Asian Journal of Plant Sciences, 5: 948955. https://doi.org/10.3923/ajps.2006.948.955.

Chapagain, N. 1991. Physiological impact of Dhobikhola (Kathmandu) water pollution of Persicaria perfoliata L. leaves and germination of some vegetable seeds. M.Sc. Thesis, Department of Botany, TribhuvanUniversity, Kathmandu. Nepal.

Chou, C.H. and Lin, H.J., 1976. Auto intoxification mechanisums of Oryza sativa L. Phytotoxic effects of decomposing rice residues in soil. Journal of Chemical Ecology, 2: 353-367. https://doi.org/10.1007/BF00988282

Coulibaly, L., Germain, G. and Spiros, A.N., 2003. Utilization of fungi for biotreatment of raw waste water. African Journal of Biotechnology, 2: 620-630. https://doi.org/10.5897/AJB2003.000-1116

David, N.S. and Rajan, M.R., 2015. Phytotoxic Effect of Dyeing Industry Effluent on Seed Germination and Early Growth of Lady's Finger. Journal of Pollution Effects and Control, 3(2): $1-4$.

Echem, O.G., 2014. Determination of the levels of heavy metal $(\mathrm{Cu}$, $\mathrm{Fe}, \mathrm{Ni}, \mathrm{Pb}$ and $\mathrm{Cd}$ ) uptake of pumpkin (Telfairia occidentalis) leaves cultivated on contaminated soil. Journal of Applied Sciences and Environmental Management, 18(1): 71-77. https://doi.org/10.4314/jasem.v18i1.10

Farooq, M., Anwar, F. and Rashid, U., 2008. Appraisal of heavy metal contents in different vegetables grown in the vicinity of an industrial area. Pakistan Journal of Botany, 40(5): 2099-2116

Haque, M. 2008. Treatment of wastewater in Bangladesh. Cotton Bangladesh. Retrieve at: http://www.cottonbangladesh.com/ april2008/wastewater.htm.

Hassan, J., Kamal, M.Z.U. and Alam, M.Z., 2013. Impact of textile dyeing effluents on germination and seedling stage of country bean (Lablab niger var. Typicus). International Research Journal of Earth Sciences, 1(4): 1-9.

ISTA. 1985. International rules for seed testing. Seed Science and Technology, 13: 421-463

Jamali, M.K., Kazi, T.G., Arain, M.B., Afridi, H.I., Jalbani, N. and Memon, A.R., 2007. Heavy metal contents of vegetables grown in soil irrigated with mixtures of wastewater and sewage sludge in Pakistan using ultrasonic-assisted pseudodigestion. Journal of Agronomy and Crop Science, 193(3): 218-228. https://doi.org/10.1111/j.1439-037X.2007.00261.x

Kannan, A. and Upreti, R.K., 2008. Influence of the distillery effluents on germination and growth of mung beans (Vigna radiata) seeds. Journal of Hazardous Materials, 153: 609-615. https://doi.org/10.1016/j.jhazmat.2007.09.004

Kisku, G.C., Barman, S.C. and Bhargava, S.K., 2000. Contamination of soil and plants with potentially toxic elements irrigated with mixed industrial effluent and its impact on the environment. Water, Air and Soil Pollution, 120: 121-137. https://doi.org/10.1023/A:1005202304584

Konwar, D. and Jha, D.K., 2010. Response of rice (Oryza sativa L.) to Contamination of Soil with Refinery Effluents under Natural Conditions. Biological and Environmental Sciences, 5(1): 1422.

Krishnaswamy, V. and Seshu, D.V., 1990. Germination after accelerate aging associated characters in rice varieties. Seed Science and Technolgy, 8: 147-150.

Mahesh, K.S., Chandrashekara, K.T., Rajashekar, N. and Jagannath, S., 2013. Physiological behaviour of few cultivars of paddy (Oryza sativa L.) during seed germination and early growth, subjecting to distillery effluent stress. International Research Journal of Biological Sciences, 2(9): 5-10.

Malla, L. and Mohanty, B.K., 2005. Effect of paper mill effluent on germination of greengram (Phaseolus aureus Roxb.) and growth behaviour of seedlings. Journal of Environmental Biology, 26: 379-382.

Marshall, F.M., Holden, J., Ghose, C., Chisala, B., Kapungwe, E., Volk, J., Agrawal, M., Agrawal, R., Sharma, R.K. and Singh, R.P. 2007. Contaminated Irrigation Water and Food Safety for the Urban and Peri-urban Poor: Appropriate Measures for Monitoring and Control from Field Research in India and Zambia, Incpetion Report DFID Enkar R8160, SPRU, University of Sussex.

Medhi, U.J., Talukdar, A.K. and Deka, S., 2008. Effect of pulp and paper mill effluents on seed germination and seedling growth of mustard (Brassica campestris), pea (Pisum sativum) and rice (Oryza sativa) seeds. Pollution Research, 27(3): 423-442.

Nawaz, S., Ali, S.M. and Yasmin, A., 2006. Effect of industrial effluents on seed germination and early growth of Cicer arietinum. Journal of Biosciences, 6: 49-54. https://doi.org/10.3923/jbs.2006.49.54

Oguntade, O.A., Adetunji, M.T., Arowoolo, T.A., Salami, F.K. and Azeez, J.O., 2014. Use of dye industry effluent for irrigation in Amaranthus cruents L. production: effect on growth, root morphology, heavy metal accumulation and safety concerns. Archives of Agronomy and Soil Science, 61(6): 865-876. https://doi.org/10.1080/03650340.2014.958820

Oncel, I., Keles, Y. and Ustun, A.S., 2000. Interactive effects of temperature and heavy metal stress on the growth and some biochemical compounds in wheat seedlings. Environmental Pollution, 107: 315-320. https://doi.org/10.1016/S02697491(99)00177-3

Otokunefor, T.V. and Obiukwu, C., 2005. Impact of refinery effluent on the physicochemical properties of a water body in the niger delta. Applied Ecology and Environmental Research, 3(1): 6172. https://doi.org/10.15666/aeer/0301_061072

Palanivel, M., Rajaguru, P., Kalaiselvi, K., Rajaram, N.S. and Ramanathan, G., 2004. Impact of dye industry effluent on seed germination and early seedling growth of Sorghum bicolor and Zea mays. Advances in Plant Sciences, 17: 717-723.

Pandey, S.N., Nautiyal, B.D. and Sharma, C.P., 2008. Pollution level in distillery effluent and its phytotoxic effect on seed germination and early growth of maize and rice. Journal of Environmental Biology, 29(2): 267-270. 
Panich-pat, T. and Srinives, P., 2009. Partitioning of lead accumulation in rice plants. Thai Journal of Agricultural Science, 42: 35-40.

Parameswari, M. and Udayasooriyan, C., 2013. Impact of textile and dye effluent irrigation on germination and its growth in cereals. Research in Environment and Life Sciences, 6(2): 69-72.

Rahman, M.A., Rayhan, M.Y.H., Chowdhury, M.A.H., Mohiuddin, K.M. and Chowdhury, M.A.K., 2018. Phytotoxic effect of synthetic dye effluents on seed germination and early growth of red amaranth. Fundamental and Applied Agriculture, 3(2): 480-490. https://doi.org/10.5455/faa.299239

Raju, K., Vishnuvardhan, V. and Damodharam, T., 2015. Industrial effluents effect on seedling growth of rice and wheat (Oryza sativa L. and Triticum vulgare L.). International Journal of Recent Scientific Research, 6(7): 4935-4939.

Rani, R. and Alikhan, M.A., 2007. Utilization of distillery effluent and its effect on growth and physiology of Oryza sativa L. Proceedongs of the National Conference on Ecofriendly Utilization of Recyclable Organic Resources from Sugar and Distillery Industries for Sustainable Agriculture, March 6-7, Trichy, pp. 1-9.

Raun, S., Xue, Q. and Thlkowska, K., 2002. Effect of seed priming on germination and health of rice (Oryza sativa L.) seeds. Seed Science and Technology, 30: 451-458.

Rohit, K.C. and Ponmurugan, P., 2013. Seed germination study of Vigna radiata using treated and untreated industrial effluents. International Journal of Latest Research in Science and Technology, 2(2): 103-104.

Salim, M., Akram, M., Akhtar, M. and Ashraf M., 2003. Rice, A production handbook, balanced fertilization for maximizing economic crop yields. Pakistan Agricultural Research Council, $2: 1$.

Samuel, S. and Muthukkaruppan, S.M., 2011. Physico-Chemical Analysis of Sugar Mill Effluent, Contaminated Soil and its Effect on Seed Germination of Paddy (Oryza sativa L.) International Journal of Pharmaceutical \& Biological Archives, 2(5): 1469-1472

Sarathchandra, U., Ghani, A., Waller, J., Burch, G., Sayer, S., Waipara, N. and Dexter, M., 2006. Impacts of caran-rich dairy factory effluent on growth of perennial ryegrass (Lolium perenne) and soil microorganisms. European Journal of Soil Biology, 42(1): 13-22. https://doi.org/10.1016/j.ejsobi.2005.08.002

Sharma, R.K., Agrawal, M. and Marshall, F.M., 2007. Heavy metals contamination of soil and vegetables in suburban areas of Varanasi, India. Ecotoxicology and Environmental Safety, 66: 258-266. . https://doi.org/10.1016/j.ecoenv.2005.11.007
Singh, A., Sharma, R.K., Agrawal, M. and Marshall, F.M., 2010. Health risk assessment of heavy metals via dietary intake of foodstuffs from the wastewater irrigated site of a dry tropical area of India. Food and Chemical Toxicology, 48: 611-619. https://doi.org/10.1016/j.fct.2009.11.041

Singh, P.K., Sharma, K.P., Kumar, S. and Sharma, S., 2007. Assessment of environmental contamination potential of distillery effluent using plant and animal bioassays. Nature, Environment and Pollution Technology, 6(1): 63-74.

Singh, P.P., Manish, M. and Singh, J., 2006. Impact of Fertilizer Factory Effluent on Seed Germination, Seedling Growth \& Chlorophyll Content of Gram (Cicer aeritinum). Journal of Environmental Biology, 27: 153-156.

Stolt, P., Asp, H. and Hultin, S., 2006. Genetic variation in wheat cadmium accumulation on soils with different cadmium concentration. Journal of Agronomy and Crop Science, 192: 201-208. https://doi.org/10.1111/j.1439-037X.2006.00202.X

Suresh, B., Abraham, K. and Damodharam, T., 2014. Effect of sugar industry effluent on changes of growth and biochemical contents of Capsicum annuum L. Advances in Applied Science Research, 5(5): 305-309.

Vaithiyanathan, T. and Sundaramoorthy, P., 2017. Analysis of sugar mill effluent and its influence on germination and growth of African marigold (Tagetes erecta L.). Applied Water Science, 7: 4715-4723. https://doi.org/10.1007/s13201-017-0634-1

Vijayaragavan, M., Vijayarengan, P., Manivasagaperumal, R., 2006. Effect of cadmium on germination and seedling growth of radish (Raphanus sativus L.). Advances in Plant Sciences, 19: 469-471.

Vinod, K., 2014. Sugar mill effluent utilization in the cultivation of maize (Zea mays L.) in two seasons. Journal of Waste Management, 12. https://doi.org/10.1155/2014/408509

Welch, R. and Graham, R., 2005. Trace Elements. Medical Biography, 18: 299-307. https://doi.org/10.1016/j.jtemb.2005.03.001

Williams, P.N., Zhang, H., Davison, W., Zhao, S., Lu, Y. and Dong, F., 2012. Evaluation of in Situ DGT measurements for predicting the concentration of $\mathrm{Cd}$ in Chinese field-cultivated rice: impact of soil Cd:Zn ratios. Environmental Science and Technology, 46(15): 8009-8016. https://doi.org/10.1021/es301195h

Yousaf, I., Ali, S.M. and Yasmin, A., 2010. Germination and early growth response of Glycine max varieties in textile and paper industry effluents. Pakistan Journal of Botany, 42(6): 38573863. 